\title{
Life history and morphological studies of Punctaria tenuissima (Chordariaceae, Phaeophyceae), a new record for the Azores
}

\author{
Manuela I. Parente ${ }^{1,2, *}$, Robert L. Fletcher ${ }^{3}$, Ana I. \\ Neto $^{2,4}$, Ian Tittley ${ }^{5}$, Ana F. Sousa ${ }^{6}$, Stefano Draisma ${ }^{7}$ \\ and Daniela Gabriel ${ }^{2}$ \\ ${ }^{1}$ Departamento de Ciências e Engenharia do Ambiente, \\ Instituto do Mar - IMAR, Faculdade de Ciências e \\ Tecnologia, Universidade Nova de Lisboa, Quinta \\ da Torre, 2829-516 Caparica, Portugal, \\ e-mail: nelaparente@ hotmail.com \\ ${ }^{2}$ Departamento Biologia, Universidade dos Açores, Rua \\ Mãe de Deus 58, Apartado 1422, P-9502, Ponta Delgada, \\ São Miguel, Açores, Portugal \\ ${ }^{3}$ University of Portsmouth, Institute of Marine Sciences, \\ Ferry Road, Eastney, Portsmouth, Hampshire, PO4 9LY, \\ UK \\ ${ }^{4}$ CIIMAR (Centro Interdisciplinar de Investigação Marinha \\ e Ambiental), Universidade do Porto, Rua dos Bragas, 289 \\ - 4050-123 Porto, Portugal \\ ${ }^{5}$ Department of Botany, The Natural History Museum, \\ Cromwell Road, London SW7 5DB, UK \\ ${ }^{6}$ Departamento de Oceanografia e Pescas, Universidade \\ dos Açores, Cais de Santa Cruz, 9901-862-Horta, Faial, \\ Açores, Portugal \\ ${ }^{7}$ Institute of Ocean and Earth Sciences, University of \\ Malaya, Kuala Lumpur 50603, Malaysia \\ * Corresponding author
}

\begin{abstract}
Punctaria tenuissima (Chordariaceae, Phaeophyceae) is reported for the first time from the Azores. Erect thalli were collected on the Island of São Miguel; they were up to $3 \mathrm{~cm}$ long, flattened and often twisted. The plurilocular sporangia were formed from surface cells that were quadrate or rectangular in surface view. Unilocular sporangia were not observed in the field. In culture, the plurispores of $P$. tenuissima developed into Hecatonema-like, tufted, prostrate thalli that formed plurilocular sporangia. The plurispores of the prostrate thalli cultured at $15^{\circ} \mathrm{C}$ with a long day (LD) photoperiod developed into new prostrate thalli, which in turn formed plurilocular sporangia. This cycle was repeated 5 times, resulting in several generations of reproductive prostrate thalli. When these cultures were cooled to $10^{\circ} \mathrm{C}$ with a short day (SD) photoperiod, new erect thalli developed from the prostrate thalli resembling the thalli collected in the field. These erect blades produced unilocular and plurilocular sporangia on the same or on different thalli. The plurispores and unispores produced by the erect thalli at $10^{\circ} \mathrm{C}$ under SD conditions once again developed into new prostrate thalli. This
\end{abstract}

is the first report of unilocular sporangia formed in cultures of $P$. tenuissima. Sexual reproduction was not observed. The culture conditions, particularly temperature and daylength, appeared to influence the formation of erect blades. The Punctaria-like thalli were produced in $10^{\circ} \mathrm{C} / \mathrm{SD}$ conditions, whilst the Hecatonema-like thalli were produced under $10^{\circ}-15^{\circ} \mathrm{C} / \mathrm{LD}$ and SD conditions. These results are similar to those reported for $P$. tenuissima from other locations and suggest the occurrence of both direct and heteromorphic life histories in the Azorean algae.

Keywords: Hecatonema terminale; life history; morphology; Phaeophyceae; Punctaria tenuissima.

\section{Introduction}

Punctaria tenuissima (C. Agardh) Greville was originally described as Zonaria tenuissima C. Agardh (Agardh 1824) based on specimens from the Kattegat, an area of sea between Sweden and Denmark. Zonaria tenuissima was subsequently transferred by Greville (1830) to the genus Punctaria. Punctaria tenuissima is characterized by the presence of dorso-ventrally flattened, solitary or gregarious, simple, thin and narrow erect blades arising from a small discoid holdfast (Fletcher 1987). This species has been reported from several locations in the temperate-to-cold north Atlantic, the Mediterranean, and the Black Sea, as well as from Burma (Myanmar) in the Indian Ocean (see Guiry and Guiry 2009), but this latter record must be considered doubtful. Hecatonema terminale (Kützing) Kylin was reported from the Azores by Parente et al. (2000) (as H. terminalis Kylin) and is the only other member of the "Punctariaceae" that has been described from this region. Hecatonema species are solitary or, more commonly, confluent microscopic tufts consisting of a basal layer that is mostly monostromatic, but in places distromatic, from which arise unbranched or scarcely branched erect filaments (Fletcher 1987). H. maculans (F.S. Collins) Sauvageau, a species very similar to $H$. terminale, has frequently been recognized as an alternate stage in the life history of blade forming members of the Punctariaceae (Clayton and Ducker 1970, Clayton 1974, Fletcher 1984, Pedersen 1984), a family currently placed in the Chordariaceae (Peters and Ramírez 2001).

Life history studies of Punctaria tenuissima have generally revealed the occurrence of an asexual, direct, monophasic life history with spores liberated from erect thalli germinating into a filamentous prostrate system from which new erect blades are produced (Kylin 1933, Rhodes 1970, Rietema and van den Hoek 1981, Lockhart 1982, Pedersen 
1984). For many isolates, environmental conditions appeared to play an important role in determining the production of the erect blades and the fertility of the microthalli (Pedersen 1984). According to Fletcher (1987), P. tenuissima may occur in different genotypes since isolates from different geographical regions vary in their responses to various environmental conditions, and he suggested that $P$. tenuissima could be subsumed under Punctaria latifolia Greville. The present study reports the occurrence of $P$. tenuissima in the Azores and describes the morphology of the algae collected as well as aspects of their development and life history in culture. Similarities between P. tenuissima and P. latifolia are discussed.

\section{Materials and methods}

Thalli of Punctaria tenuissima were collected in the intertidal in March 1999 at Feteiras, in March 2002 at Santo António Além Capelas and in March 2005 at Maia on São Miguel (coordinates $37^{\circ}-40^{\circ} \mathrm{N}$ and $25^{\circ}-31^{\circ} \mathrm{W}$ ), the largest island of the Azorean Archipelago.

For morphological studies, thalli were examined, numbered, stored in 5\% buffered formaldehyde-sea water solution and deposited in the Department of Biology, University of the Azores. The code numbers of the more representative specimens are given in the text. The entire thallus, portions or sections of specimens were observed under stereo and compound microscopes. Measurements of cells and other structures were made using a micrometer eye piece. Sections were made manually using a razor blade. In some circumstances, preparations were also made by squashing portions of thalli between slides and cover slips.

Culture studies were carried out from one thallus collected in March 2005 at Maia. The entire alga was washed in clean seawater and the surface wiped clean with portions of damp cotton wool (batting). Segments of thallus bearing plurilocular sporangia were cut out and spores were isolated following Wynne's (1969) "Hanging Drop" technique and using Grund's (von Stosch 1963) culture medium. Cultures were incubated in culture cabinets (Gallenkamp, Loughborough, UK: cooler incubator with timed cycling, regime 1 and ARALAB, Oeiras, Portugal: Fitoclima 4600, regime 2). A total of ten Petri dishes was set up, five for each regime, all containing a large number of spores. When a subsequent generation was required, fertile material was subcultured, as described previously.

Initially, the cultures were submitted to regime 1, i.e., $15^{\circ} \mathrm{C}, 16-8 \mathrm{~h}$ light-dark; after two months, six Petri dishes were deposited in another culture cabinet, representing regime $2,10^{\circ} \mathrm{C}, 8-16 \mathrm{~h}$ light-dark. Regime 1 was selected to reflect the climate conditions in the Azores at the time the cultured specimen was collected, while regime 2 was selected to reflect colder regions where the species is common. In both regimes, light was provided by white fluorescence tubes at a photon irradiance of $\sim 45-50 \mu \mathrm{mol} \mathrm{cm}{ }^{2}$ day $^{-1}$.

The different phases of development of the life cycle and the reproductive organs were photographed using an OLYM-
PUS-PM (Tokyo, Japan) 10-35 AD-1 microphotography system.

\section{Results}

Punctaria tenuissima is reported from the Azores for the first time, based on collections form São Miguel Island. It represents the only species of the genus described for the Azores.

\section{Morphology and phenology}

Specimens studied: SMG-99-497, SMG-02-105; SMG-0549. Thallus epiphytic and/or epilithic, consisting of erect blades arising from a small discoid holdfast. Blades up to $3 \mathrm{~cm}$ long, light to greenish brown in colour, dorso-ventrally flattened, solitary or gregarious, simple, thin and narrow, frequently spirally twisted with crisp margins. In surface view, cells are quadrate or rectangular, measuring $15-35 \times 13-$ $23 \mu \mathrm{m}$, each containing large numbers of discoid chloroplasts with associated pyrenoids (Figure 1A). In transverse section, blades are 1-4 cells thick, and the quadrate to rectangular cells measure 17-30×10-15 $\mu \mathrm{m}$. Phaeophycean endogenous hairs with a basal sheath are frequent, measuring $13-15 \mu \mathrm{m}$ in diameter. Plurilocular sporangia are quadrate or rectangular in surface view $(25-30 \times 18-28 \mu \mathrm{m})$ and formed from surface cells (Figure 1A). Unilocular sporangia were not observed. Epiphytic thalli grew on Pterocladiella capillacea (S.G. Gmelin) Santelices et Hommersand and Cladostephus spongiosus (Hudson) C. Agardh. Fertile thalli bearing plurilocular sporangia were only found in March 2005 at Maia.

\section{Cultures established from field-collected Punctaria tenuissima, and growth patterns in regime $1\left[15^{\circ} \mathrm{C}\right.$, 16-8 h light-dark/long days (LD)]}

The spontaneously released spores from plurilocular sporangia were pyriform, with two dissimilar flagella and contained several discoid chloroplasts and a prominent red eyespot. After 1-4 h, they began to settle, and rounded up (Figure 1B). After spore settlement, a number of cultures was set up. Within 1-3 days, each spore developed a small germ tube (Figure 1C). This culture regime resulted in the development of microthalli. Transverse divisions along the germ tube produced a short, uniseriate, branched system, often with a hair (Figure 1D). After 1-2 weeks, all sporelings produced numerous ectocarpoid plurilocular sporangia that originated from the basal cells and from cells of the erect filaments (Figure 1E, F). They were sessile or had short stalks, were 1-6 cells in length and were lateral or terminal on erect filaments. At about the same time, most of the sporelings produced long uniseriate filaments (Figure 2A) that terminated in a true hair (Figure $2 \mathrm{~B}$ ) resembling the early development of an erect blade. However, these structures never became parenchymatous. After 1 week, these filaments developed lateral uniseriate filaments and resembled an extension of the prostrate system, but after 1-2 weeks these 


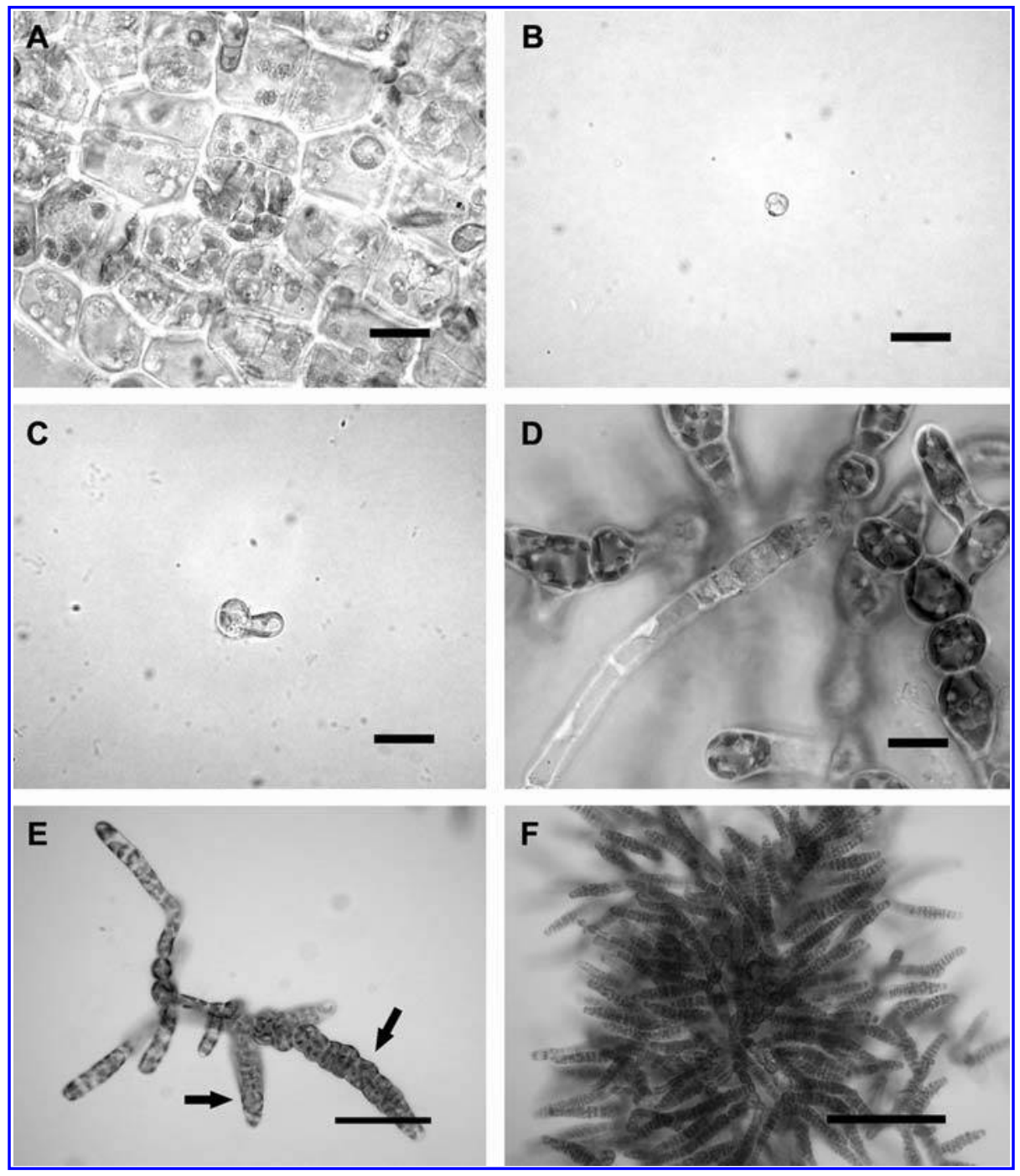

Figure 1 Punctaria tenuissima: surface view of mature thallus (collected from the sea) bearing plurilocular sporangia.

(A) Development in culture under regime $1,15^{\circ} \mathrm{C} / \mathrm{LD}$ (progeny derived from plurispores); bar $=10 \mu \mathrm{m}$. (B-F): (B) Settled spore from plurilocular sporangia (plurispore); bar $=10 \mu \mathrm{m}$. (C) Spore with small germ tube; bar=10 $\mu \mathrm{m}$. (D) Microthalli with a hair; bar=10 $\mu \mathrm{m}$. (E, F) Microthalli with ectocarpoid plurilocular sporangia (arrows); (E) bar=40 $\mu \mathrm{m},(\mathrm{F})$ bar=100 $\mu \mathrm{m}$.

filaments became colourless and died. The swarmers from the plurilocular sporangia produced in culture underwent a type of development similar to that described above for plurispores of erect thalli. All liberated spores developed directly into new microthalli. This type of life history was repeated through five generations.

\section{Cultures established from 2-month-old microthalli with plurilocular sporangia from regime $1\left(15^{\circ} \mathrm{C}\right.$, 16-8 $\mathrm{h} / \mathrm{LD})$, and growth patterns in regime $2\left[10^{\circ} \mathrm{C}\right.$, 8-16 h light-dark/short days (SD)]}

After a few weeks in regime 2, the microthalli stopped producing plurilocular sporangia and erect thalli were produced directly from the microthallus, represented by uniseriate, erect filaments with endogenous hairs with a basal sheath, as described previously under regime 1 . Later, after longi- tudinal divisions, mainly in one plane, these erect filaments became parenchymatous (Figure 2C) forming flattened and twisted blades (Figure 2D). Some blades increased in width up to eight cells, and gradually grew to resemble the erect vegetative thalli characteristic of field-collected specimens (Figure 2D); others never reached this size and remained 1-3 cells in width. The cells of the erect blades contained several discoid chloroplasts with associated pyrenoids. After two months under this regime, the erect blades developed several unilocular and plurilocular sporangia from the surface cells on the same thalli (Figure 3A). The unilocular sporangia were ovate in surface view (Figure 3B). The plurilocular sporangia were quadrate or polygonal in surface view, conical (and sometimes bifurcate) (Figure 3C, D) and protruding above the surface in vertical section.

Thallus portions with only unilocular sporangia were isolated, and the liberated unispores developed into new pros- 


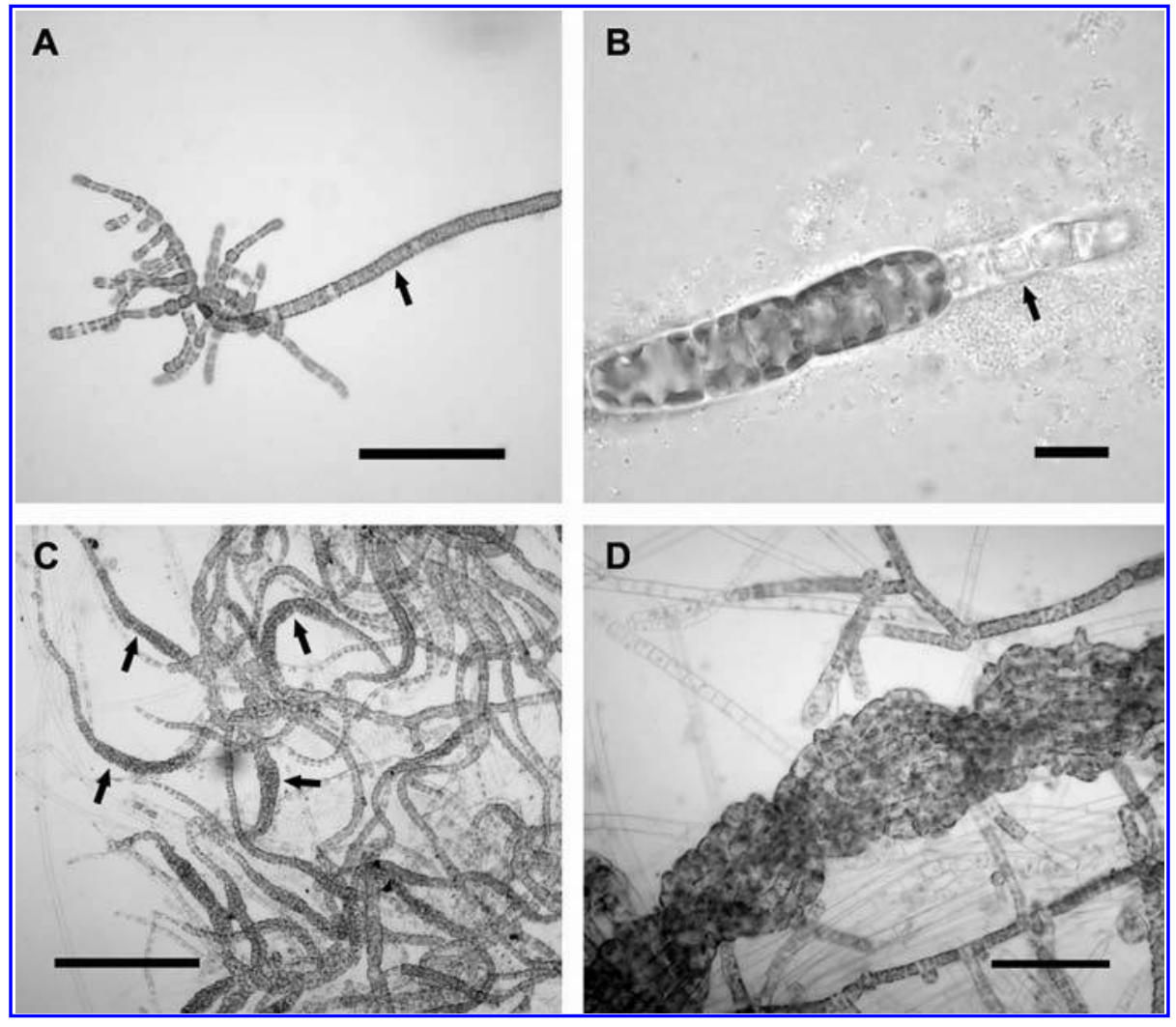

Figure 2 Punctaria tenuissima: development in culture under regime $1,15^{\circ} \mathrm{C} / \mathrm{LD}$ (progeny derived from plurispores).

(A, B): (A) Sporelings with long uniseriate filament (arrow); bar $=100 \mu \mathrm{m}$. (B) Long uniseriate filament terminated by a true hair (arrow). Development in culture under regime $2,10^{\circ} \mathrm{C} / \mathrm{SD}$; bar $=10 \mu \mathrm{m}$. (C) Numerous erect blades produced form microthalli (arrows); bar $=200 \mu \mathrm{m}$. (D) Flattened and twisted erect blades characteristic of field-collected specimens; bar $=40 \mu \mathrm{m}$.

trate thalli, as previously described. The same developmental pattern occurred for portions of thalli with plurilocular sporangia, in which the plurispores produced prostrate thalli.

Sexual fusion was not observed in any culture experiment, but no cross experiments were possible with field thalli due to the small number of specimens collected.

\section{Discussion and conclusion}

Punctaria tenuissima is newly recorded for the Azores, which now represents its southern limit of distribution in the Atlantic. The Azorean specimens are in agreement with the descriptions of $P$. tenuissima given by Fletcher (1987) and others. No major differences were observed in measurements of cells, hairs and plurilocular sporangia between Azorean and British specimens of P. tenusisima.

The present life history study of Azorean Punctaria tenuissima (Figure 4) revealed the involvement of a prostrate phase resembling a Hecatonema-type of thallus. This result finds support in the investigations of other authors (Kylin 1933, Loiseaux 1969, Clayton and Ducker 1970, Rhodes 1970, Clayton 1974, Fletcher 1984, Pedersen 1984) who have reported the involvement of Hecatonema sp. and Hecatonema-like microthalli in the life histories of species of the macroscopic genera Asperococcus and Punctaria. Earlier studies by Kylin (1933) on P. tenuissima [as Desmotrichum undulatum (J. Agardh) Reinke] revealed the occurrence of fertile microthalli in the life history similar to both $\mathrm{H}$. maculans and Ectocarpus terminalis Kützing (Guiry and Guiry 2009). Later, Pedersen (1984) identified the microthalli produced in his cultures of Asperococcus fistulosus (Hudson) Hooker as either $H$. reptans Sauvageau and Ectocarpus repens Reinke or $H$. maculans and $H$. terminalis, depending on the light level under which they were grown. Loiseaux $(1967,1969,1970)$ undertook culture studies with a number of different species of the genus Hecatonema [H. maculans, H. foecundum (Strömf.) Loiseaux, H. hispanicum (Sauvageau) Loiseaux and $H$. primarium (Setchell et N.L. Gardner) Loiseaux and H. streblonematoides (Setchell et N.L. Gardner) Loiseaux] collected from California and France (Roscoff, Brittany). She reported that $H$. maculans had a life history link with a macroscopic phase of the genus Myriotrichia. According to Pedersen (1984) and Fletcher (1987), the Myriotrichia species (probably Myriotrichia clavaeformis Harvey) identified by Loiseaux (1969) was misidentified, the correct determination being Asperococcus, probably A. fistulosus. Cultures of $H$. maculans were also established by Clayton (1974) from specimens collected in South Australia and by Fletcher (1984) from specimens collected in the British Isles. These gave rise to macrothalli resembling Punctaria latifolia/P. tenuissima and $P$. tenuissima, respectively. 


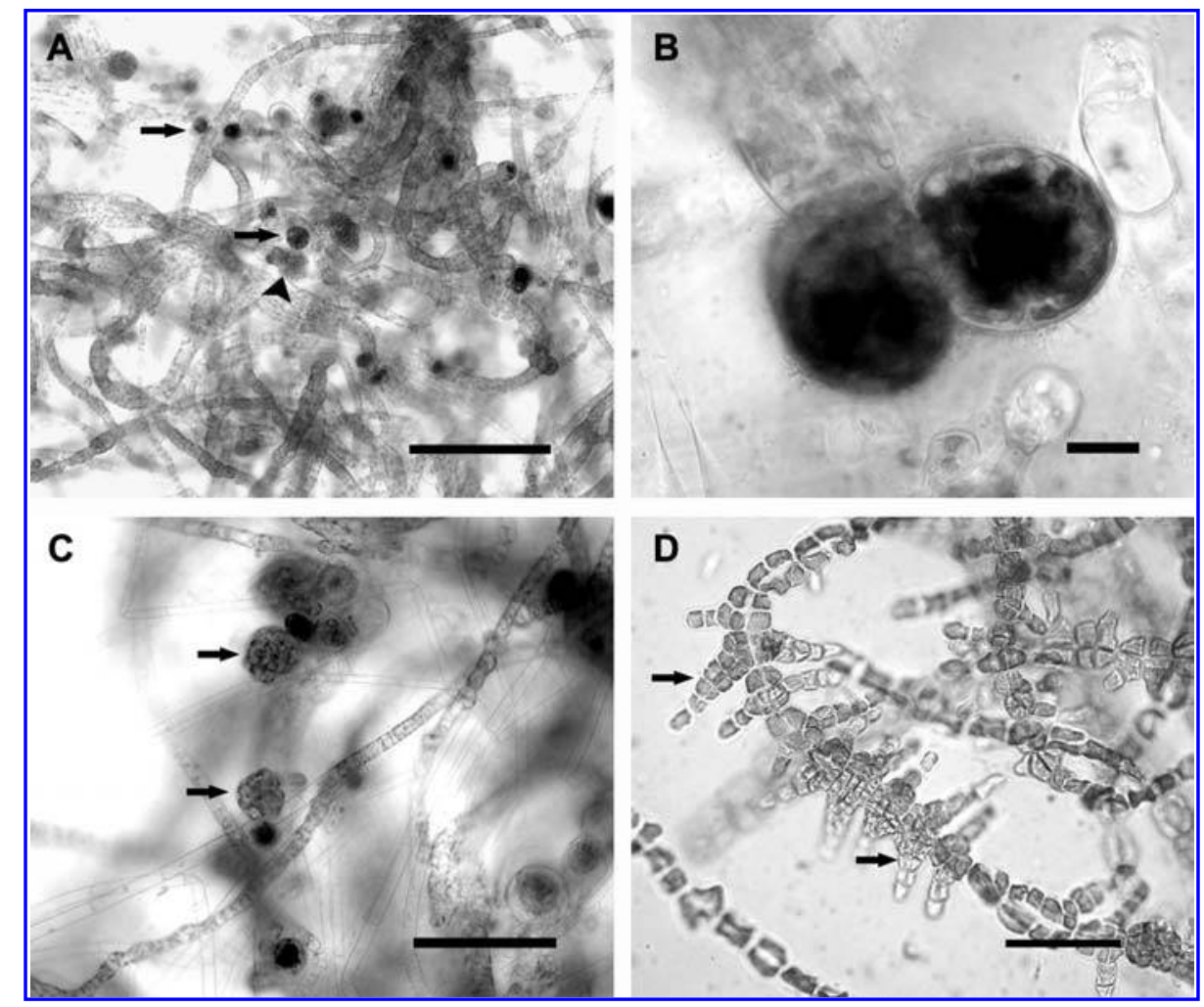

Figure 3 Development of Punctaria tenuissima in culture under regime 1, 15 $\mathrm{C} / \mathrm{SD}$ (progeny derived from plurispores).

(A, B): (A) Erect blades with uni- (arrows) and plurilocular (arrowhead) sporangia on the same thallus; bar=200 $\mu \mathrm{m}$. (B) Erect blades with rounded unilocular sporangia; bar $=10 \mu \mathrm{m}$. (C) Erect blades with quadrate to polygonal plurilocular sporangia (arrows); bar=100 $\mu \mathrm{m}$. (D) Erect blades with bifurcate, protruding plurilocular sporangia (arrows); bar $=40 \mu \mathrm{m}$.

Pedersen (1984) also reported the presence of microthalli identified as Hecatonema and Streblonema effusum Kylin in cultures of P. latifolia and P. tenuissima (as Desmotrichum undulatum), respectively, from Denmark. According to Clayton (1974), H. maculans is a heterogeneous assemblage of genotypes having, at an early stage in the development, a more or less uniform phenotype.

Interestingly, the only two "Puntariaceae" species reported for the Azores are Hecatonema terminale (Parente et al. 2000) and Punctaria tenuissima which are now found to be connected by life history. A comparison between the Hecatonema-like thalli developed in the present cultures and $H$. terminale found in nature in the Azores and other specimens from different localities (Kuckuck 1897, Børgesen 1926, Levring 1937, 1940, Fletcher 1987) revealed them to be sim-

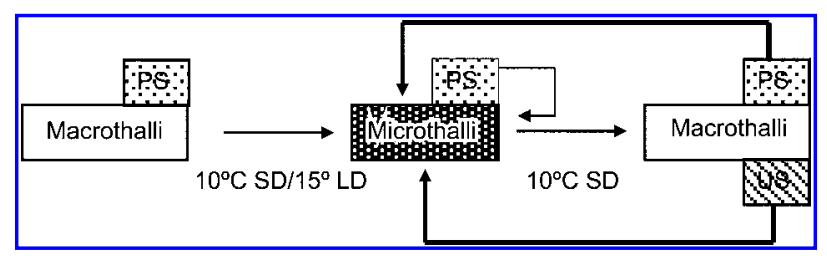

Figure 4 Punctaria tenuissima: schematic life history of Azorean specimens.

LD, long days; PS, plurilocular sporangia; SD, short days; US, unilocular sporangia. ilar (Table 1). Nevertheless, Loiseaux (1970) showed that some species of Hecatonema from California (excluding $H$. streblonematoides) developed directly into thalli identical to their parents. Similar results were obtained by Edelstein et al. (1971) working with $H$. maculans from eastern Canada and Pedersen (1984) working with specimens from Denmark. It seems, therefore, that Hecatonema species are phases in the life histories of many erect "Punctariaceae", although Hecatonema thalli also occur independently in nature.

The Hecatonema-like thallus produced in the present culture study agrees in almost all respects with the description of $H$. terminale (as Ectocarpus terminalis) given by Kuckuck (1897), Børgesen (1926) and Hamel (1931-1939). According to Kuckuck (1897) and Børgesen (1926), plurilocular sporangia can be lateral and terminal on the erect filaments. In the Azorean cultures, the plurilocular sporangia occurred in a terminal and lateral position on erect filaments and were also formed directly on the prostrate filaments which were typically monostromatic, and partly distromatic. This latter feature was not mentioned by the above authors. A partly distromatic base was, however, evident in drawings by $\mathrm{Ku}-$ ckuck (1897) of $H$. maculans from Germany and was also reported for H. maculans (Collins) Sauvageau by Fletcher (1987) from the British Isles and Hamel (1931-1939) from France. According to Levring (1937, 1940), H. maculans is a synonym of $H$. terminale and the presence of a distromatic 


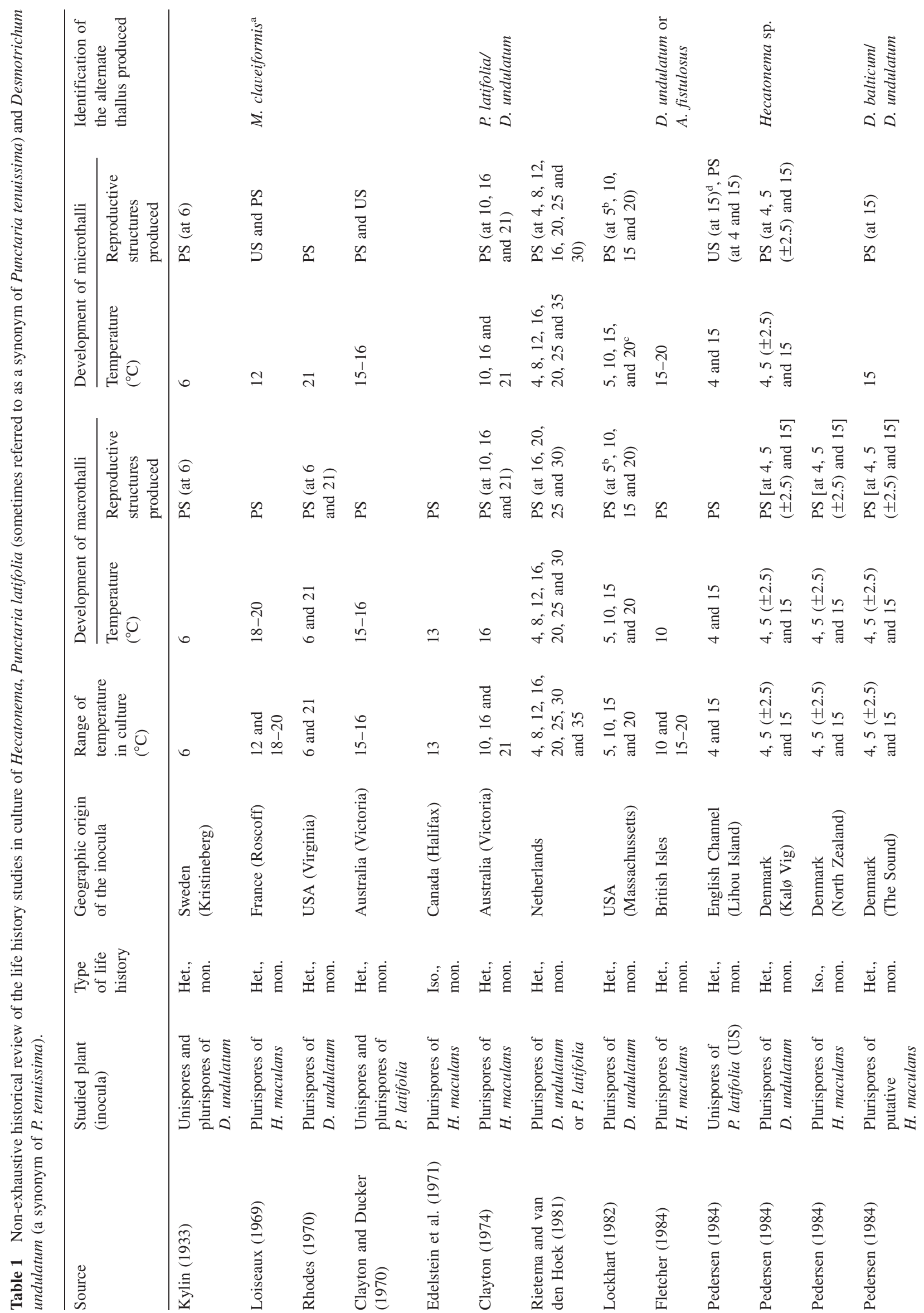




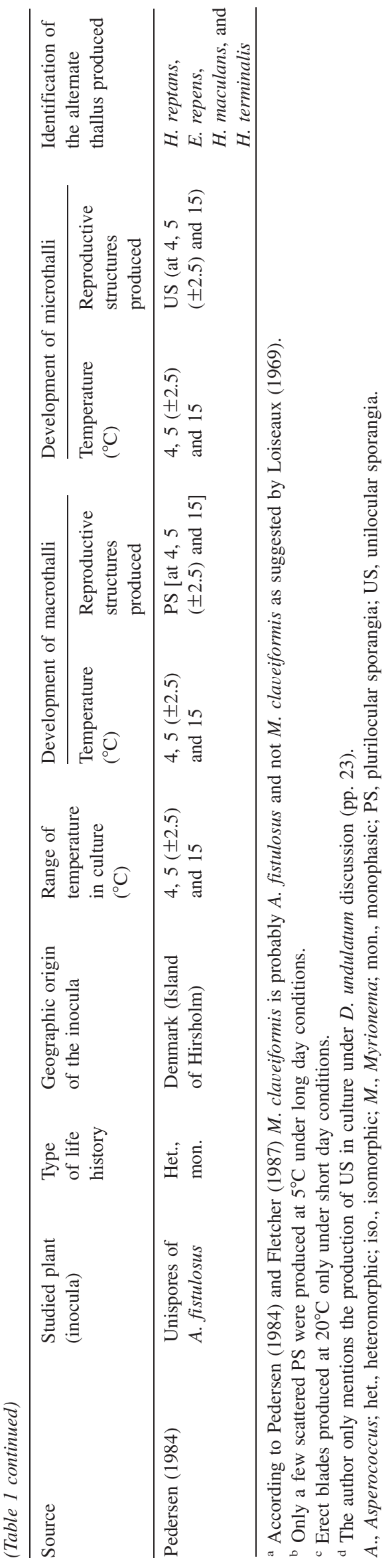

base is influenced by environmental conditions. Wynne (1998) suggests that $H$. terminale would have priority with the basionym E. terminalis Kützing. This classification has been used by Parente et al. (2000) and Guiry and Guiry (2009), but was not used by John et al. (2004) who still considered $H$. terminale and E. terminalis Kützing sensu Kuckuck as synonyms of $H$. maculans. According to John et al. (2004), E. terminalis Kützing is a young filamentous stage of Spongonema tomentosum (Hudson) Kützing, while $H$. terminale is based on E. teminalis Kützing sensu Kuckuck.

A particularly noteworthy point emerging from the present study was the occurrence of unilocular sporangia in the cultures of Azorean Punctaria tenuissima, which has not been reported previously. Unilocular sporangia were produced on the macrothalli at $10^{\circ} \mathrm{C}$ with SD conditions, and the liberated unispores developed into new microthalli in the same culture regime. P. tenuissima from the field has been described with both unilocular and plurilocular sporangia (e.g., Rietema and van den Hoek 1981, Lockhart 1982, Fletcher 1987), but the role of the unilocular sporangia and unispores has never been understood in this species. The results of the present study have revealed that the unilocular sporangia are capable of perpetuating the microthallus. It seems that both uni- and pluri-spores can play a similar role in the life history of $P$. tenuissima, although differences in ploidy were not investigated. Currently, there is no evidence of the life history being ploidy-driven in this species. It seems, however, that the production of macrothalli is facultative and influenced by environmental conditions (particularly temperature and daylength), rather than by differences in ploidy, as suggested previously by Fletcher (1987). In fact, in the present study, the Punctaria-like thallus development was observed only in $10^{\circ} \mathrm{C} / \mathrm{SD}$ conditions, whilst the Hecatonema-like thallus was produced in both $10^{\circ} \mathrm{C} / \mathrm{SD}$ and $15^{\circ} \mathrm{C} / \mathrm{LD}$ conditions. These results are in agreement with those obtained previously by Rhodes (1970, Virginia, USA). The lowest mean seawater surface temperatures in the Azores are reached in February/ March, being around $16.5^{\circ} \mathrm{C}$ since 1981 (NASA 2009). In fact, the macrothallus was initiated under regime $1\left(15^{\circ} \mathrm{C} /\right.$ LD) in the present cultures, but never became polystromatic. However, the lowest seawater surface temperatures may exceptionally reach $13^{\circ} \mathrm{C}$ (Instituto Hidrográfico 1981), and in the upper shallow pools the temperature could slightly decrease below this value, as minimum local air temperatures in winter are about $8-10^{\circ} \mathrm{C}$ (Instituto Hidrográfico 1981). The sporadic occurrence of the macrothallus of P. tenuissima in the Azores could be due to temperature responses. In fact, P. tenuissima has its Atlantic southernmost limit of distribution in the Azores. P. tenuissima was collected only in March, whereas Hecatonema has been reported to be present in the Azores all year round (Parente et al. 2000). These are different from the results obtained by Rietema and van den Hoek (1981, Netherlands) and Pedersen (1984, Denmark) working with (continental) European material. These authors showed that macrothallus formation was not temperature controlled. In the present study, however, isolates of $P$. tenuissima from the Azores responded differently to envi- 
ronmental conditions in comparison with isolates from different geographical regions, which is in agreement with observations made by Pedersen (1984) and Fletcher (1987).

Pertinent to this discussion is the supposition of Rietema and van den Hoek (1981) and Fletcher (1987) that Punctaria tenuissima could be a synonym of $P$. latifolia. This was not accepted by Pedersen (1984) who compared the two species in culture and found some differences between them, for example the influence of temperature on the number of plurilocular sporangia formed in culture, the absence of fertile juvenile stages in cultures of $P$. latifolia, and the absence of unilocular sporangia produced in cultures of $P$. tenuissima. This latter difference is questioned in view of the results of the present study, where unilocular sporangia were produced on erect macrothalli under regime 1 conditions $\left(10^{\circ} \mathrm{C} 8: 16 \mathrm{~h}\right.$ light-dark/SD). These results suggest that $P$. tenuissima and $P$. latifolia are conspecific and the former should be regarded as synonym of $P$. latifolia. The influence of temperature on the number of plurilocular sporangia formed and the absence of fertile juvenile stages in cultures of $P$. latifolia seem insufficient to distinguish the two species. The limited DNA sequence data that are available also supports conspecificity of P. tenuissima, P. latifolia, and Hecatonema maculans. A Danish isolate of P. tenuissima (GenBank accession number AF207816) was found to differ by only two base substitutions from a Korean isolate of $P$. latifolia (AY095322) in a stretch of 520 base pairs (bp) of the $r b c \mathrm{~L}$ gene, and was found to be identical to a Danish isolate of Hecatonema sp. [AF055401, tentatively named $H$. maculans by Siemer (1998)]. In the complete $r b c \mathrm{~L}$ (1467 bp), Danish Hecatonema sp. still differs by only two bp from Korean P. latifolia. The two bp difference $(<0.14 \%)$ can be due to isolation by distance and falls well within the intraspecific variation for this gene in brown algae (Kogame et al. 1999, Cho et al. 2003, 2004, Cho and Boo 2006). P. plantaginea (Roth) Greville (AF055410, Greenland) differs by 28 bp (1.91\%) from both Hecatonema. sp. and P. latifolia.

\section{Acknowledgements}

Thanks are due to many Institutions. M.I. Parente was supported by grants SFRH/BD/6566/2001 and SFRH/BPD/34246/2006 and D. Gabriel by grant SFRH/BD/12541/2003 (FCT, Fundação para a Ciência e a Tecnologia) of the Portuguese government. This work was also supported by Centro de Investigação de Recursos Naturais (CIRN, FCT) during the PhD thesis studies of the first and seventh authors, and by the Instituto do Mar (IMAR, FCT) during the postdoc grant period of the first author and by Direcção Regional da Ciência e Tecnologia (Government of the Azores) during the Science and Technology Management grant period of D. Gabriel. The work performed in the present study complies with the current laws of Portugal.

\section{References}

Agardh, C.A. 1824. Systema algarum. Lundae (Lund): Literis Berlingianis. pp. xxxviii +312 .

Børgesen, F. 1926. Marine algae from the Canary Islands especially from Teneriffe and Gran Canaria II. Phaeophyceae. Biol. Meddr. 6: $1-112$.

Cho, G.Y. and S.M. Boo. 2006. Phylogenetic position of Petrospongium rugosum (Ectocarpales, Phaeophyceae): insights from the protein-coding plastid $r b c \mathrm{~L}$ and $p s a \mathrm{~A}$ gene sequences. Cryptogamie Algol. 27: 3-15.

Cho, G.Y., S.H. Lee and S.M. Boo. 2004. A new brown algal order, Ishigeales (Phaeophyceae), established on the basis of plastid protein-coding $r b c \mathrm{~L}, p s a \mathrm{~A}$, and $p s b \mathrm{~A}$ region comparisons. $J$. Phvcol. 40: 921-936.

Cho, T.O., G.Y. Cho, H.S. Yoon, S.M. Boo and W.J. Lee. 2003. New records of Myelophycus cavus (Scytosiphonaceae, Phaeophyceae) in Korea and the taxonomic position of the genus on the basis of a plastid DNA phylogeny. Nova Hedwigia 76: 381-397.

Clayton, M.N. 1974. Studies on the development, life history and taxonomy of Ectocarpales (Phaeophyta) in southern Australia. Aust. J. Bot. 22: 743-813.

Clayton, M.N. and S.C. Ducker. 1970. The life history of Punctaria latifolia Greville (Phaeophyta) in southern Australia. Aust. J. Bot. 18: 293-300.

Edelstein, T., L.C.-M. Chen and J. McLachlan. 1971. On the life histories of some brown algae from eastern Canada. Can. J. Bot. 49: $1247-1251$

Fletcher, R.L. 1984. Observations on the life history of the brown alga Hecatonema maculans (Ectocarpales, Myrionemataceae) in laboratory culture. Br. Phycol. J. 19: 193.

Fletcher, R.L. 1987. Seaweeds of the British Isles. Vol. 3. Fucophyceae (Phaeophyceae). Part 1. British Museum (Natural History), London. pp. ix +359 .

Greville, R.K. 1830. Algae britannicae, or descriptions of the marine and other inarticulated plants of the British islands, belonging to the order Algae; with plates illustrative of the genera. Edinburgh \& London: McLachlan \& Stewart; Baldwin \& Cradock, London. pp. 1xxxviii +218 .

Guiry, M.D. and G.M. Guiry. 2009. AlgaeBase. World-wide electronic publication, National University of Ireland, Galway. http:// www.algaebase.org; searched on 02 February 2009.

Hamel, G. 1931-1939. Phéophycées de France. Fasc. II. Paris, published by the author. pp. 432 .

Instituto Hidrográfico. 1981. Roteiro do Arquipélago dos Açores. PUB. (N)-IH-128-SN. pp. 237.

John, D.M., W.F. Prud'homme van Reine, G.W. Lawson, T.B. Kostermans and J.H. Price. 2004. A taxonomic and geographical catalogue of the seaweeds of the western coast of Africa and adjacent islands. Beih. Nova Hedwigia 127: 1-339.

Kogame, K., T. Horiguchi and M. Masuda. 1999. Phylogeny of the order Scytosiphonales (Phaeophyceae) based on DNA sequences of $r b c \mathrm{~L}$, partial $r b c \mathrm{~S}$, and partial LSU nr DNA. Phycologia 38 : 496-502.

Kuckuck, P. 1897. Bemerkungen zur marinen Algenvegetation von Helgoland. II. Wiss. Meeresunters. (Helgol.) N. F. 2: 371-400.

Kylin, H. 1933. Über die Entwicklungsgeschichte der Phaeophyceen. Lunds Univ. Åsskr. N. F. Avd. 2 43: 1-100.

Levring, T. 1937. Zur Kenntnis der Algenflora der Norwegischen Westküste. Lunds Univ. Årsskr. 33: 1-147.

Levring, T. 1940. Studien über die Algenvegetation von Blekinge, Südschweden. Lund. pp. 179.

Lockhart, J.C. 1982. Influence of light, temperature and nitrogen on morphogenesis of Desmotrichum undulatum (J. Agardh) Reinke (Phaeophyta, Punctariaceae). Phycologia 21: 264-272.

Loiseaux, S. 1967. Recherches sur les cycles de développement des Myrionématacées (Phéophycées). I-II. Hécatonématées et Myrionématées. Rev. Gén. Bot. 74: 529-576.

Loiseaux, S. 1969. Sur une espèce de Myriotrichia obtenue en cul- 
ture à partir de zoïdes d'Hecatonema maculans Sauv. Phycologia 8: $11-15$.

Loiseaux, S. 1970. Notes on several Myrionemataceae from California using culture studies. J. Phycol. 6: 248-260.

National Aeronautics and Space Administration (NASA). 2009. Ocean motion and surface currents. 16, February, 2009. http:// oceanmotion.org/html/resources/ssedv.htm.

Parente, M.I., R.L. Fletcher and A.I. Neto. 2000. New records of brown algae (Phaeophyta) from the Azores. Hydrobiologia 440: 153-157.

Pedersen, P.M. 1984. Studies on primitive brown algae (Fucophyceae). Opera Bot. 74: 1-76.

Peters, A.F. and M.E. Ramírez. 2001. Molecular phylogeny of small brown algae, with special reference to the systematic position of Caepidium antarcticum (Adenocystaceae, Ectocarpales). Crvptogam. Algol. 22: 187-200.

Rhodes, R.G. 1970. Relation of temperature to development of the macrothallus of Desmotrichum undulatum. J. Phycol. 6: 312314.
Rietema, H. and C. van den Hoek. 1981. The life history of Desmotrichum undulatum (Phaeophyceae) and its regulation by temperature and light conditions. Mar. Ecol. Prog. Ser. 4: 321-335.

Siemer, B.L. 1998. Molecular phylogenetic studies in the simple brown algae - Ectocarpales, Chordariales, Dictyosiphonales, Scytosiphonales and Tilopteridales. $\mathrm{PhD}$ thesis University of Copenhagen, Denmark. pp. 138.

von Stosch, H.A. 1963. Wirkungen von Jod und Arsenit auf Meeresalgen in Kultur. Proc. Int. Seaweed Symp. 4: 142-150.

Wynne, M.J. 1969. Life history and systematic studies of some Pacific North American Phaeophyceae (brown algae). Univ. Calif. Pub. Bot. 50: 1-88.

Wynne, M.J. 1998. A checklist of benthic marine algae of the tropical and subtropical western Atlantic: first revision. Nova Hedwigia Beihefte 116: 1-155.

Received 5 November, 2009; accepted 9 March, 2010 